\title{
EVALUASI EFEKTIVITAS PERATURAN DAERAH NOMOR 22 TAHUN 2014 TENTANG RETRIBUSI PELAYANAN PERSAMPAHAN DAN KEBERSIHAN DALAM MENINGKATKAN PENDAPATAN ASLI DAERAH (Studi di Kota Palangka Raya )
}

\author{
MERBU WAHYUDI
}

\begin{abstract}
This study of the resreach to describe and analyze : (1) Describe and analiyze Effectivenees of Local Regulation Number 22 of 2014 on Retribution Waste and Sanitation Services to Intrease the Original Income. (2) Supporting Factors and Inhibiting Effectivenees of Local Regulation Number 22 of 2014 on Retribution Waste and Sanitation Services to Intrease the Original Income. There are 5 (five) Effectivenees Indicators A Program : Namely the succes of the program, target sucess, satisfaction with the program, input and output levels, the achievement of the overall objectives. In the resreach the resreachers used the method Qualitative descriptive. Data Collection techniques using ways observation, interview, and documentation. Based on Resreach results : (1) Local Regulation Number 22 of 2014 on Retribution Waste and Sanitation Palangka Raya City done pretty well and the ralization of the Distribution of waste and sanitation sectors the government has always achived, however still not maximal between input and output due to lack of facilities and infrastructure and community participation and negligence to pay compulsory retribution. This is analyzed from 5 (five) indicators of the effectivenees a program : lack off facilities and infrastructure garbage transport and lack of cooperation between related agencies in the event on sanctions for violations of regional regulations is an onternal factor resulting in a lack of quality waste and sanitation in the Palangka Raya City. And external factors ie lack of awareness and community participation paying retribution and lack of understanding to the important functions and roles of the community in increasing local revenue from the retribution sector so that this local regulation has not been implemented effectively and efficiently. (2) Supporting Factors : the efforts of the relevant agencies to maximize service to the community by making various efforts evaluation of constraints faced and what should be improved in improving service and community participation.(3) Suggestion: The importance of cooperation with related agencies enforcement of sanctions violation of obligation of pay retribution as well proper socialization to raise awareness and public participation in paying levies on garbage and sanitation services of course by improving supporting facilities an infrastructure which can be perceived by the Society.
\end{abstract}

Keywords: Effectivenees Local Regulation, In improving original Income, Retribution Waste and Sanitation. 


\section{PENDAHULUAN}

Kota Palangka Raya merupakan Kota yang berjuluk "Kota Cantik" tersebut memiliki harapan bahwa kota Palangka Raya yang Bersih, rapi dan nyaman dapat dirasakan oleh masyarakat yang berada di Kota Palangka Raya. Oleh karena itu Pemerntah Kota Palangka Raya Dalam Peraturan Daerah Kota Palangka Raya Nomor 19 Tahun 2011, Pasal 1 ayat (11) menyatakan sampah adalah semua benda atau Produk sisa dalam bentuk padat, setengah padat yang teridiri dari bahan organik dan non organik, baik logam maupun non logam yang dapat terbakar atau tidak, sebagai akibat aktivitas manusia yang dianggap tidak bermanfaat lagi dan tidak dikehendaki oleh pemiliknya dan dibuang sebagai barang yang tidak berguna, didalamnya tidak termasuk sampah dalam kategori Bahan Berbahaya Beracun (B3).Dalam Peraturan Daerah Nomor 19 Tahun 2011 Pasal 8 ayat 3 dijelaskan tetang besaran tarif-tarif retribusi untuk masing-masing objek retribusi Pelayanan Persampahan dan Kebersihan dimana menurut pengamatan peneliti bahwa pemerintah Daerah melaksanakan Pemungutan Retribusi Daerah disesuaikan dengan pertimbangan dan berbagai aspek yang mendukung dan mempengaruhi Pemungutan Retribusi tersebut, sehingga dalam upaya Peningkatan Pendapatan Asli Daerah maka Pemerintah Daerah mengeluarkan Peraturan Daerah Kota Palangka Raya Nomor 22 Tahun 2014 yang memuat tentang rincian besaran tarif Retribusi Pelayanan Persampahan dan Kebersihan Kota Palangka Raya dengan memperhatikan faktor-faktor tertentu yang dapat memberikan Pemasukan dalam Kas Daerah dengan melihat keadaan serta Proses pembangunan di Kota Palangka Raya seperti adanya gedung, atau bangunan, maupun kegiatan-kegiatan masyarakat yang dapat menyumbang sumber sampah sehingga pemerintah Daerah berupaya untuk menangani sampah yang dihasilkan oleh masyarakat Kota Palangka Raya yang tentunya memperhatikan keadaan serta Penetapan tarif Retribusi yang tepat sasaran dan dapat bermanfaat terhadap Peningkatan Pendapatan Asli Daerah dan seluruh warga Masyarakat Kota Palangka Raya secara khusus. Dalam Penelitian ini peneliti tertarik untuk mengamati dan meninjau bagaimana efektivitas Peraturan Daerah tentang Retribusi Pelayanan Persampahan dan Kebersihan Kota Palangka Raya dalam menujang Peningkatan Pendapatan Asli Daerah (PAD) dari sektor retribusi, apakah Peraturan Daerah tersebut berjalan efektif dalam upaya Peningkatan Pendapatan Asli Daerah serta meninjau bagaimana Partisipasi dan Tanggapan Masyarakat tentang Pelaksanaan Retribusi tersebut. Tujuan utama dari Peraturan Daerah Tentang Retribusi Kebersihan dan Persampahan ini untuk meningkatkan pelayanan kepada masyarakat serta bagaimana starategi dan upaya Pemerintah dalam meningkatkan Pendapatan Asli Daerah dari sektor Retribusi Pelayanan Persampahan dan Kebersihan di Kota Palangka Raya dengan tetap memperhatikan Tata Kota Palangka Raya yang Bersih, dan Nyaman.

Dengan ditetapkannya Peraturan Daerah Kota Palangka Raya Nomor 22 Tahun 2014 yang memuat tentang Perubahan atas Peraturan Daerah Nomor 19 Tahun 2011 Tentang Retribusi Persampahan dan Kebersihan Kota Palangka Raya. Yang didalamnya memuat tentang Aturan, tata cara, dan besaran tarif Retribusi Pelayanan Kebersihan dan Persampahan Kota Palangka Raya, peneliti bermaksud untuk melihat dan mengamati kembali bagaimana efektivitas Peraturan Daerah Retribusi Pelayanan Persampahan dan Kebersihan Kota Palangka Raya dalam 
menunjang Pendapatan Asli Daerah dari sektor Retribusi, dan faktor apa saja yang penghambat dan pendukung Efektivitas dari Peraturan Daerah tersebut serta strategi apa saja yang diupayakan Pemerintah Kota Palangka Raya dalam pelaksanaan Peraturan Daerah tersebut .

Berdasarkan latar belakang masalah diatas maka Penulis termotivasi untuk melakukan Penelitian berjudul "EVALUASI EFEKTIVITAS PERATURAN DAERAH NOMOR 22 TAHUN 2014 TENTANG RETRIBUSI PELAYANAN PERSAMPAHAN DAN KEBERSIHAN DALAM MENINGKATKAN PENDAPATAN ASLI DAERAH" (Studi di Kota Palangka Raya).

\section{TINJAUAN PUSTAKA}

\section{Konsep dan Pengertian Evaluasi}

Pengertian Evaluasi dalam Kamus Besar Bahasa Indonesia berarti penilaian; hasil. Menurut Bryan \& White (1987), evaluasi adalah upaya untuk mendokumentasi dan melakukan penilaian tentang apa apa yang terjadi dan mengapa hal itu terjadi, evaluasi yang paling sederhana adalah mengumpulkan informasi tentang keadaan sebelum dan sesudah pelaksanaan suatu program/perencanaan.

Pengertian Evaluasi menurut Charles O. Jones dalam Aprilia (2009) adalah : evaluasi adalah kegiatan yang dapat menyumbangkan pengertian yang besar nilainya dan dapat pula membantu penyempurnaan pelaksanaan kebijakan serta pelaksanaannya. Penjelasan tersebut menjelaskan bahwa kegiatan evaluasi dapat mengetahui apakah pelaksanaan suatu program sudah sesuai dengan tujuan utama, yang selanjutnya kegiatan evaluasi tersebut dapat menjadi tolak ukur apakah suatu kebijakan atau kegiatan dikatakan layak diteruskan, perlu diperbaiki atau dihentikan kegiatannya.

Menurut PP Nomor 39 Tahun 2006tentang Tata Cara Pengendalian dan Evaluasi Pelaksanaan Rencana Pembangunan, didalam pelaksanaannya, kegiatan evaluasi dapat dilakukan dalam berbagai tahapan yang berbeda yaitu :

a. Evaluasi tahap perncanaan (ex-ante), yaitu evaluasi yang dilakukan pelaksanaan rencana pembangunan dengan tujuan untuk memilih dan menentukan skala prioritas dari berbagai alternatif dan kemungkinan cara mencapai tujuan yang dirumuskan sebelumnya;

b. Evaluasi pada tahap pelaksanaan (on-going), yaitu evaluasi dilakukan pada saat pelaksanaan rencana pembangunan untuk menentukan tingkat kemajuan pelaksanaan rencana dibandingkan dengan rencana yang telah ditentukan sebelumnya, dan

c. Evaluasi pada tahap pasca-pelaksanaan (ex-post), yaitu evaluasi yang dilakukan setelah pelaksanaan berakhir, yang diarahkan untuk melihat apakah pencapaian (keluaran/hasil/dampak) program mampu mengatasi masalah pembangunan yang ingin dipecahkan. Evaluasi ini dilakukan untuk mengetahui efisiensi (keluaran dan hasil dibandingkan masukan), efektivitas (hasil dan dampak terhadap sasaran), ataupun manfaat (dampak tehadap kebutuhan) dari suatu program. 


\section{Efektivitas}

\section{Konsep dan Pengertian Pengertian Efektivitas}

Hasibuan dalam Handayaningrat (1996:16) bahwa,"Efektivitas adalah tercapainya suatu sasaran eksplitit dan implisit". Secara kompeherensif, efektivitas dapat diartikan sebagai tingkat kemampuan suatu lembaga atau organisasi untuk dapat melaksanakan semua tugas-tugas pokoknya atau dapat mecapai sasaran yang telah ditentukan sebelumnya. Artinya bahwa efektivitas berhubungan dengan dimensi waktu atau penyelesaian pekerjaan sesuai dengan waktu yang ditentukan sebelumnya. Apabila tujuan atau sasaran dapat dicapai, sesuai dengan waktu yang ditentukan sebelumnya maka dikatakan efektif, akan tetapi apabila tujuan atau ssaran yang dihasilkan tidak tepat penyelesaiannya seusai dengan waktu yang telah ditentukan maka dikatakan tidak efektif. Berdasarkan pendapat tersebut diatas, maka Penulis menyimpulkan bahwa yang dimaksud dengan efektivitas adalah tercapainya suatu tujuan dan sasaran yang telah ditentukan sebelumnya sesuai dengan waktu yang telah ditentukan.

\section{Indikator Efektivitas}

Indikator efektivitas adalah sarana atau alat ukur untuk mengukur hasil suatu Aktivitas, kegiatan atau proses. Menurut Pendapat Gibson et.al (1996:30) menyebutkan bahwa "masing-masing tingkat efektivitas dapat dipandang sebagai suatu sebab variabel oleh variabel lain (ini berarti sebab efektivitas)".

Berdasarkan sebab diatas bahwa tingkat efektivitas merupakan suatu sebab variabel berpengaruh terhadap variabel lain. Adanya suatu variabel yang mempengaruhi variabel lain menjadi sebab variabel yang terikat dapat berjalan efektif. Efektivitas dapat dipengaruhi oleh banyak faktor . Faktor-faktor yang mepengaruhi tersebut diantaranya adalah faktor internal maupun faktor eksternal suatu organisasi. Menurut Cambel J.P, pengukuran efektivitas secara umum yang paling menonjol adalah :

a. Keberhasilan Program.

b. Keberhasilan Sasaran.

c. Kepuasan Terhadap Program.

d. Tingkat Input dan Output.

e. Pencapaian tujuan menyeluruh

\section{Retribusi Daerah}

Sesuai dengan Undang-Undang nomor 34 tahun 2000 tentang perubahan undang-undang Nomor 18 Tahun 1997 tentang Pajak Daerah dan Retribusi Daerah, Pasal 1 angka 26 menyatakan bahwa : Di indonesia saat ini penarikan retribusi hanya dapat dipungut oleh pemerintah daerah. Jadi, retribusi yang dipungut di Indonesia dewasa ini adalah retribusi daerah. Retribusi Daerah adalah pemungutan daerah sebagai pembayaran atas jasa atau diberikan pemerintah daerah untuk kepentingan orang pribadi atau badan. Retribusi ini berdasarkan atas peraturan yang berlaku, yakni dalam bentuk peraturan Daerah dan untuk menaatinya yang berkepentingan dapat dipaksa (paksaan ekonomis) yaitu, barangsiapa yang ingin 
menggunakan/mendapat jasa tertentu dari pemerintah, maka ia wajib membayarnya. Pembayaran inilah yang disebut dengan Retribusi.

\section{Objek, Golongan, dan Fungsi Retribusi Daerah}

Undang-undang Nomor 34 Tahun 2000 Tentang Pajak Daerah dan retribusi Daerah, Pasal 18 ayat (1) menentukan bahwa objek retribusi adalah berbagai jenis jasa tertentu yang disediakan oleh pemerintah daerah. Tidak semua jasa yang diberikan oleh pemerintah dapat dijadikan objek retribusi, tetapi hanya jenis-jenis jasa tertentu yang menurut perimbangan sosial-ekonomi layak dijadikan sebagai objek retribusi. Petapan jenis-jenis retribusi jasa umum dan jasa usaha dengan peraturan pemerintah dimaksudkan agar terciptanya ketertiban daam penyelenggaraan nya sehingga dapat memberikan kepastian bagi masyarakat dan disesuaikan dengan kebutuhan nyata daerah yang bersangkutan. Penetapan jenisjenis retribusi perizinan tersebut, walaupun merupakan kewenangan pemerintah daerah, tetap memerlukan koordinasi dengan instansi-instansi terkait.

Retribusi hanya semata-mata untuk mengisi Kas Negara maupun Daerah sebagai penggantian yang telah dikeluarkan dalam upaya penyediaan sarana pelayanan kepada masyarakat. (Munawir, 1985:16). Dengan demikian, pemerintah dilarang memungut retribusi kepada masyarakat, jika tidak memafaatkan sarana pelayanan yang disediakan. Misalnya, terhadap masyarakat yang tidak menggunakan pasar sebagai tempat melakukan kegiatan ekonomi, pemerintah dilarang memungut retribusi pasar.

\section{Perhitungan, Pemungutan, dan Hukum Retribusi Pelayanan Persampahan dan Kebersihan}

Bedasarkan Pasal 151 ayat (1) Undang-Undang Nomor 28 Tahun 2009 tentang Pajak Daerah dan Retribusi Daerah bahwa besarnya Retribusi yang terutang oleh orang Pribadi atau badan yang menggunakan jasa atau Perizinan tertentu dihitung dengan tingkat penggunaan jasa. Dengan demikian, besarnya Retribusi yang terutang dihitung berdasarkan tarif Retribusi dan tingkat penggunaan jasa. Cara Perhitungan Retribusi, besarnya Retribusi Daerah yang harus dibayar oleh pribadi atau badan yang menggunakan jasa yang bersangkutan dihitung dari perkalian antara tarif Retribusi dan tingkat penggunaan jasa dengan rumus sebagai berikut :

Retribusi Terutang $=$ Tarif retribusi $\mathrm{x}$ Tingkat Penggunaan Jasa

Selain Undang-Undang Nomor 19 Tahun 1997 tentang Pajak Daerah dan Retribusi Daerah Pasal 26 Pemungutan Retribusi tidak dapat diborongkan yang terdapat pula dalam Peraturan daerah Kota Palangka Raya Nomor 19 Tahun 2011. Artinya seluruh proses pemungutan Retribusi tidak dapat diserahkan kepada pihak ketiga. Namun dalam pengertian ini bukan berarti bahwa Pemerintah Daerah tidak boleh bekerja sama dengan pihak ketiga. Dengan sangat selektif dalam proses pemungutan retribusi, pemerintah daerah dapat mengajak bekerjasama badanbadan tertentu yang karena profesionalitasnya layak dipercaya untuk ikut melaksanakan sebagian tugas pemungutan jenis Retribusi tertentu secara lebih efisien. 
Setiap jenis Retribusi Daerah yang diberlakukan di Indonesia harus berdasarkan dasar hukum yang kuat untuk melancarkan pengenaan dan pemungutannya. Demikian ini yang menjadi dasar hukum pemungutan Retribusi Daerah dan pelayanan Persampahan dan Kebersihan di Kota Palangkaraya sebagaimana dibawah ini,

1. Pasal 18 ayat (6) Undang-Undang Dasar Negara Republik Indonesia Tahun 1945;

2. Undang-undang Nomor 5 Tahun 1960, Tentang Peraturan Dasar Pokok Agraria (Lembaran Negara Republik Indoesia Tahun 1960 Nomor 104, Tambahan Lembaraan Negara Indonesia Nomor 2013);

3. Undang-ndang Nomor 5 Tahun 1965 tentang pembentukan Kotapradja Palangka Raya (Lembaran Negara Republik Indonesia Tahun 1965 omor 48, tambahan Lembaran Negara Republik Indonesia Nomor 2753);

4. Undang-Undang Nomor 33 Tahun 204 tetang Perimbangan Keuangan antara Pemerintah Pusat dan Pemerintah Daerah (Lembaran Negara Republik Indonesia Tahun 2004 Nomor 126, Tambahan Lembaran Negara Republik Indonesia Nomor 4438);

5. Undang-Undang Nomor 18 Tahun 2008 Tentang Pengelolaan sampah (Lembaran Negara Republik Indonesia Nomor 69, tambahan Lembaran Negara Republik Indonesia Nomor 4851);

6. Undang-undang Nomor 208 Tahun 2009 tentang Pajak Daerah da Retribusi Daerah (Lembaran Negara Republik Indonesia Tahun 2009 Nomor 130, Tambahan Lembaran Negara Republik Indonesia Nomor 5049);

7. Undang-Undang 32 Tahun 2009 tentang Perlindungan dan Pengelolaan Lingkungan Hidup (Lembaran Negara Republik Indonesia Tahun 2009 Nomor 140, Tambahan Lembaran Negara Republik Indonesia Nomor 5059);

8. Undang-Undang Nomor 36 Tahun 2009 tentang Kesehatan (Lembaran Negara Republik Indonesia Tahun 2009 Nomor 144, Tambahan Lembaran Negara Republik Indonesia Nomor 5063);

9. Undang-Undang Nomor 2011 tetang Pembentukan Peraturan Perundangundangan (Lembaran Negara Republik Indonesia Tahun 2011 Nomor 82, Tambahan Lembaran Negara Republik Indonesia Nomor 4389);

10. Undang-Undang Nomor 23 Tahun 2014 tentang Pemerintah Daerah (Lembaran Negara Republik Indonesia Tahun 2014 Nomor 244, Tambahan Lembaran Negara Republik Indonesia Nomor 5587);

11. Peraturan Daerah Nomor 58 Tahun 2005 Tentang Pengelolaan Keeuangan Daerah Undangan (Lembaran Negara Republik Indonesia Tahun 2005 Nomor 140, Tambahan Lembaran Negara Republik Indonesia Nomor 4578);

12. Peraturan Pemerintah Nomor 6 Tahun 2006 Tentang Pengelolaan Barang Milik Negara/Daerah (Lembaran Negara Republik Indonesia Tahun 2006 Nomor 20, Tambahan Lebaran Negara Republik Indonesia Nomor 4609);

13. Peraturan Pemerintah Nomor 38 Tahun 2007 tentang pembagian Urusan Antara Pemerintah Daerah Kabupaten/Kota (Lembaran Negara Republik 
Indonesia Tahun 2007 Nomor 82, Tambahan Lembaran Negara Republik Indonesia Nomor 4737);

14. Peraturan Pemerintah Nomor 69 Tahun 2010 tentag Cara Pemberaan dan Pemanfaata Insentif Pemungutan Pajak Daerah dan Retribusi Daerah (Lembaran Negara Republik Indonesia Tahun 2010 Nomor 119, Tambahan Lembaran Negara Republik Indonesia Nomor 5161);

15. Peraturan Menteri Dalam Negeri Nomor 33 Tahun 2010 tetang Pedoman Pengelolaan Sampah (Berita Negara Republik Indonesia Tahun 2010 Nomor 274);

16. Peraturan Menteri Dalam Negeri Nomor 1 Tahun 2014 tetang Pembentukan Produk Hukum Daerah (Berita Negara Republik Indonesia Tahun 2014 Nomor 32);

17. Peraturan Daera Nomor 03 Tahun 2006 Tentang Pengelolaan Kebersihan Lingkungan dan Pertamanan (Berita Negara Republik Indonesia Tahun 2006 Nomor 03);

18. Peraturan Daerah Kota Palangka Raya Nomor 12 Tahun 2008 tetang Organisasi dan Tata Kerja Dinas Daerah Kota Palngka Raya (Lembaran Daerah Kota Palangka Raya Tahun 2006 Nomor 03, Tambahan Daerah Kota Palanga Raya Nomor 05);

19. Peraturan Daerah Kota Palangka Raya Nomor 19 Tahun 2011 tentang Retribusi Pelayanan Persampahan/Kebersihan (Lembaran Daerah Kota Palangka Raya Nomor 19 Tahun 2011, Tambahan Daerah Kota Palanga Raya Nomor 06 Tahun 2011);

20. Keputusan Bupati/walikota yang mengatur tentang Retribusi pelayanan Persampahan/Kebersihan sebagai aturan Pelaksanaan Peraturan Daerah tentang Retribusi Pelayanan Persampahan/Kebersihan Pada Kota yang dimaksud.

\section{Objek Pelayanan Persampahan dan Kebersihan}

Pengertian pelayanan menurut Kamus Besar Bahasa Indonesia dijelaskan sebagai kegiatan atau usaha melayanai kebutuhan oraang lain. Sedangkan melayani adalah, membantu menyiapkan, atau mengurus segala sesuatu yang dibutuhkan orang lain. Menurut Moenir (1992:16), untuk memenuhi kebutuhan hidupnya manusia berusaha, baik sendiri maupun secara tidak langsung melalui aktivitas orang lain. Objek Retribusi Pelayanan Persampahan/Kebersihan sebagaimana dimaksud dalam Pasal 110 ayat (1) huruf b dalam Undang-Undang Nomor 28 Tahun 2009 tentang pelayanan Persampahan dan Kebersihan yang diselenggarakan Pemerintah Daerah meliputi :

a. Pengambilan pengumpulan sampah dari sumbernya ke lokasi pembuangan sementara;

b. Pengangkutan sampah dari sumbernya dan/atau lokasi pembuangan sementara ke lokasi pembuangan/pembuangan akhir sampah;dan

c. Penyediaan lokasi pembuangan/pemusnahan akhir sampah; 


\section{METODOLOGI PENELITIAN}

Jenis penelitian yang digunakan dalam penulisan ini adalah metode deskriptif dengan pendekatan kualitatif, makna dari deskriptif adalah penelitian yang dilakukan kepada manusia, objek, suatu set kondisi, suatu sistem pemikiran ataupun suatu kelas peristiwa menurut Moh.Nazir (2005:54).

Untuk mendapatkan data-data Penelitian, peneliti menganmbil data dari Dinas Perumahan Rakyat dan Kawasan Permukiman Kota Palangka Raya, Aadapun Objek dari Penelitian Peneliti memilih Kota Palangka Raya karena peneliti menganggap bahwa Kota Palangka Raya merupakan Kota yang sedang berkembang dengan adanya Gedung-gedung yang dibangun, atau bangunan serta kegiatan Masyarakat yang dapat menyumbang sumber sampah. Sehingga Pemerintah Daerah berupaya untuk menangani sampah yang dihasilkan di Kota Palangka Raya dengan memperhatikan keadaan serta penetapan tarif Retribusi yang tepat sasaran dan bermanfaat terhadap Peningkatan Pendapatan Asli Daerah dari Sektor Retribusi. Teknik Pengumpulan data dengan cara Observasi, Wawancara, dan Dokumentasi. Aanalisis data dilakukan dengan model Interaktif dari Miles dan Huberman.

\section{KESIMPULAN}

Berdasarkan Penelitian yang Penulis lakukan, maka dapat disimpulkan :

Suatu Peraturan Daerah dapat dikatakan efektif apabila sasaran atau tujuan yang ditentukan sebelumnya dapat tercapai sesuai dengan yang telah ditentukan sebelumnya. Tingkat efektivitas merupakan suatu sebab yang mempengaruhi variabel satu dengan variabel lainnya. Efektif atau tidaknya suatu Peraturan Daerah dipengaruhi oleh banyak faktor yang diantaranya adalah faktor Eksternal dan Internal dari suatu Organisasi. Dalam hal efektif atau tidaknya Peraturan Daerah Kota Palangka Raya tentang Retribusi Pelayanan Persampahan dan Kebersihan dalam meningkatkan Pendapatan Asli Daerah tentu dipegaruhi faktor tersebut diatas, berdasarkan penelitian yang dilakukan maka dapat ditarik suatu kesimpulan bahwa adanya faktor internal dan eksternal yang dihadapi Dinas terkait dalam meningkatkan Retribusi Pelayanan Persampahan dan Kebersihan di Kota Palangka Raya, seperti kurangnya sarana dan prasarana yang disediakan oleh pemerintah dalam menunjang pelayanan persampahan dan kebersihan, serta kurangnya kesadaran masyarakat untuk berpartisipasi dalam membayar Retribusi pelayanan persampahan dan kebersihan. Meskipun pada kenyataannya bahwa tareget realisasi Retribusi Pelayanan Persampahan dan Kebersihan yang telah ditetapkan oleh Pemerintah selalu tercapai setiap tahunnya namun hal ini masih perlu dimaksimalkan guna meningkatkan Pendapatan Asli Daerah dari Sektor tersebut. Oleh karena itu Pemerintah juga perlu memperbaiki masalah internal nya untuk meningkatkan Pelayanan kepada masyarakat, serta melakukan sosialisasi kepada masyarakat untuk ikut dalam membayar retribusi sesuai dengan aturan dan tata cara yang berlaku dan perlunya kesadaran hukum dan ketaatan hukum dari masyarakat guna menunjang Pendapatan Asli Daerah untuk mengisi Kas Negara maupun Daerah dalam penyediaan sarana dan Prasarana Kepada Masyarakat dan menjadi suatu tolak ukur kinerja Perekonomian suatu Daerah. 


\section{SARAN}

Saran dari Penulis untuk Evaluasi Efektivitas Peraturan Daerah Nomor 22 Tahun 2014 tentang Retribusi Pelayanan Persampahan dan Kebersihan Kota Palangka Raya adalah sebagai berikut :

a. Pentingnya Peningkatan Pelayanan Persampahan dan Kebersihan Kota Palangka Raya guna meningkatkan kesadaran kualitas pelayanan kepada masyarakat agar masyarakat dapat merasakan manfaat dari Retribusi itu sendiri.

b. Perlu adanya kerjasama yang nyata antara Dinas dengan Pihak lain baik Pemerintah Kota maupun Pihak penegak hukum dari Pelaksanaan Peraturan Daerah tersebut sehingga Peraturan Daerah yang ada dapat berjalan lebih maksimal guna mengatasi permasalahan, membangun dan mensejahterakan masyarakatnya.

c. Dinas terkait perlu mengadakan sosialisasi kepada Masyarakat Kota Palangka Raya terkait Peran serta dan Fungsi dan manfaat dari Retribusi Pelayanan Persampahan tersebut, bukan hanya untuk menumbuhkan kesadaran Hukum dan Ketaatan Hukum dari masyarakat tetapi Untuk meningkatkan Partisipasi Masyarakat dalam Meningkatkan Pendapatan Asli Daerah dari Retribusi Tersebut.

d. Perlu adanya Suatu tindakan dan Ketegasan dari Pemerintah dalam melaksanakan Peraturan Daerah tersebut terhadap masyarakat yang lalai dan tidak melaksanakan kewajibannya dalam membayar Retribusi pelayanan Persampahan dan Kebersihan.

e. Guna meningkatkan Kesadaran dan Partisipasi Masyarakat dalam membayar Retribusi Pelayanan Persampahan dan Kebersihan maka Pelayanan kepada masyarakat baik dengan meningkatkan Kualitas Sarana maupun Prasarana pendukung dan Pelayanan yang Lebih baik kepada masyarakat.

f. Peningkatan Sarana dan Prasarana penunjang misalnya Pengadaan kendraan angkutan sampah, petugas kebersihan, dan pengadaan TPS yang lebih banyak dan dapat diakses oleh masyarakat secara merata, serta peningkatan Kualitas pelayanan lainnya.

g. Adanya Evaluasi yang nyata terhadap Peraturan Daerah tentang Retribusi Persampahan dan Kebersihan di Kota Palangka Raya sehingga Dinas terkait dan Pemerintah dapat lebih maksimal dalam realisasi Retribusi tersebut sebab Retribusi yang didapat dari Retribusi Pelayanan Persampahan dan Kebersihan tersebut disadari memang sangat tinggi jika adanya kesadaran dan partisipasi masyarakat.

\section{DAFTAR PUSTAKA}

Abdurahman. 2003. Efektivitas Organisasi. Jakarta : PT Grafindo Perkasa.

Adrian Sutedi. 2008. Hukum Pajak dan Retribusi Daerah. Ghalia Indonesia : Bogor Selatan. 
Aminudin, Muhammad. 2007. Evaluasi Rencana Lokasi Pemindahan Terminal Induk Km.6 Banjarmasin. (tesis). MPKD Universitas Gajah Mada: Yogyakarta.

Apriadi. 1989. Menghindari, Mengolah dan Menyingkirkan Sampah. Abdi Tandur: Jakarta.

Aprilia, Hera. 2009. Evaluasi Pelaksanaan Program Transmigrasi Lokal Model Ring I Pola Nelayan di Bugel, Kec. Panjatam, Kab. Kulon Progo dan Gesing Kidul. (Tesis). MPKD Universitas Gajah Mada : Yogyakarta.

Bryan, Carolie dan G. White. 1987. Manajemen Pembangunan Untuk Negara Berkembang. LP3S : Jakarta.

Mamang, Eta dan Safiah. Metodologi Penelitian. ANDI OFFSET : Yogyakarta.

Marihot P. Siahaan. 2006. Pajak dan Retribusi Daerah. PT Raja Grafindo : Jakarta.

Moenir H.A.S. 1992. Manajemen Pelayanan Umum di Indonesia, Bumu Aksara : Jakarta.

Peraturan Daerah Kota Palangka Raya Nomor 19 Tahun 2011 Tentang Retribusi Pelayanan Persampahan dan Kebersihan.

Peraturan Daerah Kota Palangka Raya Nomor 22 Tahun 2014 tentang Perubahan atas Peraturan Daerah Kota Palangka Raya Nomor 19 Tahun 2011 tentang Retribusi Pelayanan Persampahan/Kebersihan.

Peraturan Pemerintah Nomor 39 Tahun 2006 tentang Tata Cara Pengendalian dan Evaluasi Pelaksanaan Rencana Pembangunan.

Scriven, M. 1991. Evaluation thesaurus (4th ed). Newbury Park, CA: Sage. (www.hrfp.org. Diakses 26 Mei 2017)

Siswanto Sunarno. 2008. Hukum Pemerintahan di Daerah Indonesia. Sinar Grafika : Jakarta.

Soerjono Soekanto. 2004. Pokok-Pokok Sosiologi Hukum. PT Raja Grafindo Perkasa : Jakarta.

Steers, Richard. 1980. Efektivitas Organisasi. Jakarta : Erlangga

Undang-Undang Dasar Negara Republik Indonesia

Undang-Undang Dasar Tahun 1945 Amandemen ke 4.

Undang-Undang Nomor 18 Tahun 2008 tentang Pengelolaaan Sampah.

Undang-Undang Nomor 28 Tahun 2009 Tentang Pajak Daerah dan Retribusi Daerah.

Undang-Undang Nomor 32 Tahun 2004 tentang Pemerintahan Daerah.

Undang-Undang Nomor 33 Tahun 2004 tentang Pemerintahan Daerah.

Undang-Undang Nomor 34 Tahun 2000 mengenai perubahan atas Undang-Undang Nomor 18 Tahun 1997 tentang Pajak Daerah dan Retribusi Daerah. 
JISPAR, Jurnal IImu Sosial, Politik dan Pemerintahan. Volume 7, Issue 1 (2018) ISSN 2089-6123

Zainuddin Ali. 2006. Sosiologi Hukum. Sinar Grafika : Jakarta.

Zuliyanti. 2005. Konsep Pelayanan Publik. Jakarta : Rineka Cipta. 